\title{
APPLICATION OF CANWET AND HSPF FOR TMDL EVALUATION UNDER SOUTHERN ONTARIO CONDITIONS
}

\author{
Amanjot Singh ${ }^{1}$, R P Rudra ${ }^{1}$, I Ahmed ${ }^{1}$, S Das ${ }^{1}$, B Gharabaghi ${ }^{1}$, and P K Goel ${ }^{2}$ \\ ${ }^{1}$ School of Engineering, University of Guelph, Canada. ${ }^{2}$ Ontario Ministry of Environment, Canada.
}

Abstract. The CANWET (Canadian ArcView Nutrient and Water Evaluation Tool) and HSPF (Hydrologic Simulation Program - FORTRAN) models were applied to Upper Canagagigue Creek watershed of the Grand River basin in southern Ontario, Canada, for hydrology and sediment evaluations. Both the models have similarity in structure where CANWET is simpler, both in algorithms and use, than HSPF. The outputs of both the models for water budgeting components were compared on annual, seasonal, and monthly basis. The water budget components, evapotranspiration, surface runoff, and subsurface runoff produced by both the models were comparable on annual and seasonal time steps; however, there were some discrepancies in monthly and daily simulations. The seasonal, monthly, and daily Nash-Sutcliffe efficiency coefficient with observed stream flows were 0.83, 0.81, and 0.48 for HSPF, respectively, and 0.80, 0.67, and 0.24 for CANWET, respectively. The monthly and daily simulations by HSPF model were better since HSPF algorithm has more control on temporal variation in parameters sensitive for hydrologic simulations. The sediment simulations by both the models were consistently close for erosion and sediment yield on annual basis. However, superiority in predictions for total suspended sediment yield of one model over the other could not be concluded because of lack of observed data. The daily load of sediment modeled by HSPF followed flow peaks and available observed sediment data points.

Keywords. HSPF, CANWET, Watershed modeling, Source Water Protection.

\section{INTRODUCTION}

The Source Water Protection Act has been passed by Ontario Ministry of Environment (MOE) and received the royal assent for implementation in Ontario, Canada (MOE, 2006a). The conservation authorities and other government agencies are currently involved in assessment phase of drinking water sources and their focus is on assessing water budget at watershed scale. Two systems, the surface water system and groundwater system, are being worked upon and different tools researched for quantifying elements of both the systems individually and in integration. The surface water budgeting demands that how well the components of surface water system; evapotranspiration, surface runoff, interflow, baseflow, and deep percolation, can be simulated to get an understanding of the hydrology of an area. The MOE has described the components of water budget that play a key role in source water protection and suggests to follow watershed based approach for evaluation of these components (MOE, 2006b). The MOE guidelines also suggest number of available watershed modeling tools which could be implemented based upon their suitability for the area of application. The two models, Hydrologic Simulation Program - FORTRAN (HSPF) (Bicknell et al., 2001) and Canadian ArcView Nutrient and Water Evaluation Tool (CANWET) (Anonymous, 2004) were selected for comparison and suitability of use for watersheds in southern Ontario. Both the models operate under different complexities and are currently being used by various agencies and consultants in Ontario to address source water protection objectives.

The CANWET model is the Canadian version of Generalized Watershed Loading Function model (GWLF) developed at Cornell University, NY, USA by Haith et al. (1992). The model uses the concept of HSPF in simplified form (Haith, 2006) and also uses land use based approach for hydrologic simulations but with limited parameters, which makes the model application simple. The CANWET/GWLF models have been widely used for hydrology and non-point source pollution simulations from watersheds (ShuKuang et al, 2006; Benham et al., 2005). Similarly, the HSPF model has also been extensively used for hydrological and total maximum daily load (TMDL) modeling (Singh et al., 2005; Al-Abed and Whiteley, 2002). The HSPF model is more comprehensive compared to CANWET, involves large number of variables, and uses complex approaches in simulating watershed hydrology and pollutants. A theoretical comparison of number of watershed models including HSPF and GWLF was done by Borah and Bera (2003). Now with the availability of models with varied complexities in use and approach, question arises that how much complexity do we need for water budgeting and total maximum daily load (TMDL) assessment? Therefore, the presented study was conducted with the objectives to compare the components of the two models for water budgeting and sediment simulation. The evaluation will give users a feeling of the strengths and weakness of the two models. 


\section{MATERIALS AND METHODS}

The two models, HSPF and CANWET, selected for comparison of water budgeting and sediment simulations in addressing source water protection objectives were applied to the Canagagigue Creek watershed of Grand River basin in southern Ontario, Canada. The surface water loadings for both the models is distributed in the sense that it allows multiple land use/cover scenarios, but each area is assumed to be homogenous in regard to various attributes considered by the model. Additionally, the models do not spatially distribute the source areas, but simply aggregate the loads from each area into a watershed total The brief description of models on hydrologic and sediment simulation approaches is presented below:

Hydrologic Simulation Program - FORTRAN (HSPF)

HSPF, the Hydrological Simulation Program - FORTRAN (Bicknell et al., 2001) is a continuous watershed simulation model that produces a time history of water quantity and quality distributed over a watershed. The model has three main modules, PERLAND, IMPLAND, and RCHRES. PERLAND represents permeable (non-urban agricultural and forest) lands, IMPLAND represents impermeable (urban/developed) lands, and RCHRES represents streams/rivers in the watershed. HSPF estimates surface runoff using hourly time step as a function of infiltration computed using Philip's equation (Philip, 1957). The model uses a storage routing technique to route water form one reach to the next during stream processes. For the sediment simulations it uses model developed by Negev (1967).

Canadian ArcView Nutrient and Water Evaluation Tool (CANWET)

The CANWET (Anonymous, 2004) is a GIS-based model and is modified version of the GWLF (Generalized Watershed Loading Function) model developed by Haith et al. (1992). The model has two main modules, Rural and Urban. Rural module is similar to PERLAND module of HSPF and Urban similar to IMPLAND. The CANWET model provides a continuous stream flow simulation using daily time steps for weather data and water balance calculations. It uses Soil Conservation Services (SCS) curve number approach (USDA-SCS, 1972) for surface runoff generation and universal soil loss equation (USLE) (Wischmeier and Smith, 1965) for soil erosion calculations. Monthly calculations are made for sediment and nutrient loads based on the sum of daily water balance values for a given month. The spatial routing is not available in the current version. For subsurface loading, the model acts as a lumped parameter model using a daily water balance methodology. Daily water budgets are computed for an unsaturated zone as well as a saturated subsurface zone, where infiltration is simply computed as the difference between precipitation and snowmelt minus surface runoff and evapotranspiration. Evapotranspiration is determined using daily weather data and a cover factor dependent upon land use and cover type.

Study area

The site selected for the study is a portion of Canagagigue Creek watershed, upstream of the Floradale reservoir and is located between $43^{0} 36^{\prime} \mathrm{N}-43^{\circ} 42^{\prime} \mathrm{N}$ latitude and $80^{\circ} 33^{\prime} \mathrm{W}-80^{\circ} 38^{\prime} \mathrm{W}$ longitude. The Canagagigue Creek watershed is a sub-watershed of Grand River basin in southern Ontario, Canada; a major river draining $7000 \mathrm{~km}^{2}$ area into Lake Erie. The upper Canagagigue Creek watershed drains approximately 53 square kilometers (5,262 hectares). Over $79.4 \%$ of this area is under agricultural land use, $11.3 \%$ forest and wetlands, $9 \%$ pasture, $0.2 \%$ built up and $0.1 \%$ is open water. Elevation in the watershed ranges from 362 to 470 meters and $97 \%$ of the area has a slope of less than five per cent. The soils in the watershed belong to Guelph, Harriston, Dumfries, Burford, and Waterloo series and are broadly categorized as silt and silt loam.

Discretization of watershed

The delineation and discretization of watershed into sub-basins for HSPF and CANWET application was performed using EPA-BASINS automatic delineation tool (USEPA, 2001). The three GIS layers, the 10 $\mathrm{m}$ resolution digital elevation model (DEM), land use grid layer, and soils grid layer, were obtained from the Grand River Conservation Authority (GRCA). The Canagagigue Creek watershed was delineated on the upstream of the Floradale reservoir and downstream of the confluence of the two tributaries draining eastern and western part of the watershed. A 100 ha threshold area was selected for stream definition. The land uses were classified into agriculture, hay/pasture, forest, and urban. The same discretization and land use practices were used to simulate hydrology and sediment yield from both the models.

The HSPF and CANWET model parameters used for the study were calibrated from the range suggested by different studies conducted to evaluate HSPF and CANWET/GWLF (USEPA, 2000; Anonymous, 2004; Haith et al., 1992).

Model evaluation

The calibrated models were compared for water budget components, stream flow, and total suspended 
sediment load (TSS) on annual, seasonal, monthly, and daily time steps. The evaluation and comparison was done both statistically and visually. The Nash-Sutcliffe efficiency coefficient (Nash-E) (Nash and Sutcliffe, 1970) and scattered plotting were used for statistical comparison of outputs of the models with each other and with the observed data.

\section{RESULTS AND DISCUSSION}

\section{Annual Water Budget}

The averaged annual components of water budget (subsurface runoff, surface runoff, and evapotranspiration) simulated by HSPF and CANWET were compared (Fig. 1). The HSPF simulated that $62 \%$ of the water budget was constituted by evapotranspiration (ET), $19 \%$ by interflow, $11 \%$ by groundwater flow, and $8 \%$ by surface runoff. Similarly CANWET simulated water budget components was $63 \%$ evapotranspiration, $28 \%$ subsurface flow (interflow + groundwater flow), and $9 \%$ surface runoff. The outputs of both the models revealed that the water budget components were comparable. Dickinson and Rudra (2006) also found similar division of rainfall into ET, surface runoff, and subsurface from the watersheds with medium textured soils in Ontario.

The annual stream flow simulated by HSPF and CANWET compared well with the observed stream flow for the years 1993-95 and averaged annual stream flow (Fig. 2). Therefore, at this stage of comparison it is understandable that both HSPF and CANWET simulated well and either can be used for annual budgeting of water.

HSPF

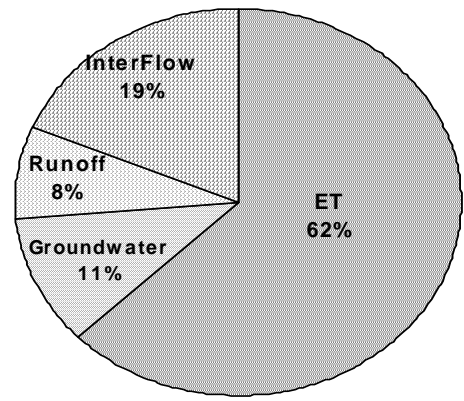

CANWET

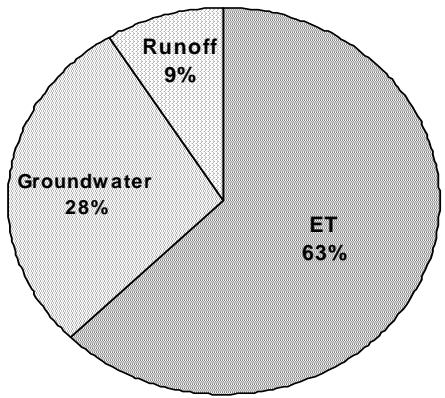

Fig. 1. Average annual water budget simulated by HSPF and CANWET (1993-1995)

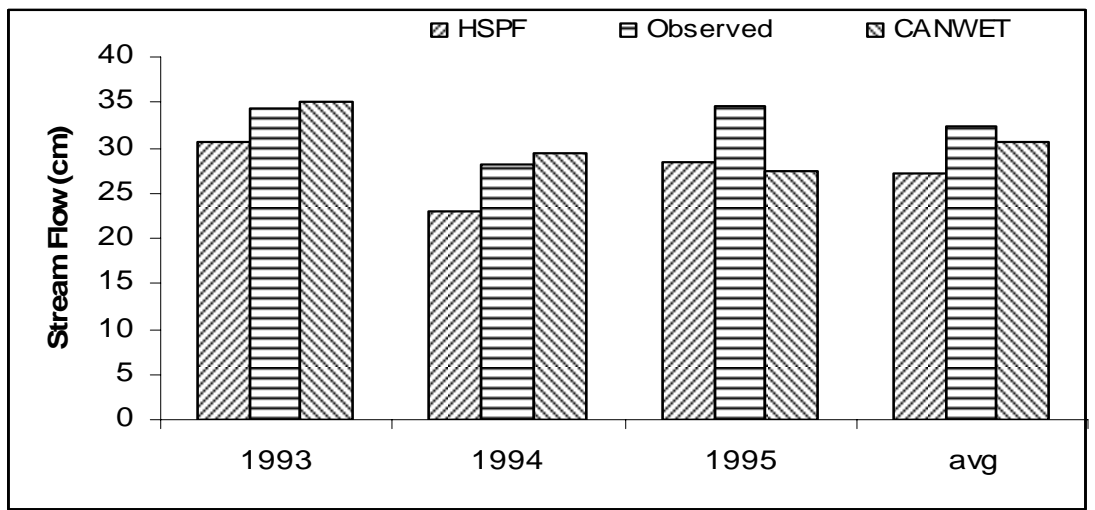

Fig. 2. Comparison of annual and averaged annual stream flow simulated by HSPF and CANWET with observed stream flow.

Seasonal Water Budget

The seasonal results of the water budget components simulated by HSPF and CANWET (Table 1) 
indicate close agreement between ET, surface runoff, subsurface runoff, and stream flow. Further, the HSPF and CANWET simulated stream flows were compared with the observed stream flow. The comparison indicated high Nash-E of 0.83 for HSPF and 0.80 for CANWET for seasonal stream flow for the period between 1993 and 1995. Both the models under predicted steam flow during winter; HSPF under predicted during spring whereas CANWET over predicted; both predicted well during summer whereas HSPF predicted well during fall but CANWET under predicted. Overall, HSPF under predicted stream flow whereas as predictions varied in case of CANWET. Moreover, HSPF simulated less surface runoff and more subsurface runoff than CANWET. The observations in southern Ontario reveal that most of the flows in stream during summer results from the subsurface (groundwater) contribution. Therefore, the observations imply that HSPF performed more realistically in simulating the subsurface flow in summer than CANWET.

Table 1. Seasonal water budget components simulated by HSPF and CANWET

\begin{tabular}{|c|c|c|c|c|c|c|c|c|c|c|}
\hline \multirow[t]{3}{*}{ Season } & \multicolumn{10}{|c|}{ Water budget parameters $(\mathrm{cm})$} \\
\hline & \multicolumn{2}{|c|}{ Evapotranspiration } & \multicolumn{2}{|c|}{$\underline{\text { Surface Runoff }}$} & \multicolumn{2}{|c|}{$\begin{array}{c}\text { Subsurface } \\
\text { Flow }\end{array}$} & \multicolumn{2}{|c|}{$\begin{array}{c}\text { Subsurface flow } \\
\text { split (HSPF) }\end{array}$} & \multicolumn{2}{|c|}{$\underline{\text { Stream Flow }}$} \\
\hline & 1 & 2 & 1 & 2 & 1 & 2 & 3 & 4 & 1 & 2 \\
\hline Winter & 0.3 & 0.4 & 2.8 & 2.1 & 5.6 & 6.2 & 3.0 & 2.6 & 8.4 & 8.2 \\
\hline Spring & 9.2 & 9.8 & 2.6 & 3.5 & 9.8 & 13.3 & 7.6 & 2.2 & 12.4 & 16.9 \\
\hline Summer & 32.7 & 37.0 & 0.3 & 1.0 & 2.9 & 2.6 & 1.3 & 1.6 & 3.2 & 3.5 \\
\hline Fall & 3.8 & 3.8 & 0.2 & 0.8 & 3.0 & 1.1 & 1.6 & 1.4 & 3.2 & 1.9 \\
\hline
\end{tabular}

1=HSPF, 2=CANWET, 3=Interflow, 4=groundwater flow, Winter=December, January, and February; Spring=March-May; Summer=June-September; Fall=October-November

Monthly Water Budget

The water budget components of HSPF and CANWET were analyzed for monthly simulations from 1993-1995. The simulation by HSPF (Fig. 3) indicates that evapotranspiration is minimal in January-March and Nov-December $(0.0-0.48 \mathrm{~cm})$ and kicks up in April $(2.1-3.2 \mathrm{~cm})$ with peak evapotranspiration in the month of July $(9.0-11.2 \mathrm{~cm})$. Simulated surface runoff shows a general trend of higher flows during January $(1.5-3.5 \mathrm{~cm})$ and March-April $(0.1-2.4 \mathrm{~cm})$. HSPF produced maximum interflow in January, March and November $(0.1-3.5 \mathrm{~cm})$ and the groundwater contribution remained steady between $0.2-1.4 \mathrm{~cm}$ with minimum percent contribution during summer months of July-September $(0.2-0.6 \mathrm{~cm})$. Looking at the monthly maximum contribution of water budget components, evapotranspiration contributed more than $90 \%$ of the water budget during months from June-September; surface runoff contributed $47.8 \%$ in January and $38 \%$ in March; interflow contributed close to 50\% from February to April; and groundwater $48.7 \%$ in February and 59.3\% in December.

The simulation by CANWET (Fig. 3) shows the similar trends with evapotranspiration ranging between 0.0-1.11 cm during January-March and Nov-December and 1.42-2.36 cm in April with peak in the month of July (10.9-12.2 cm); surface runoff maximum in 0.0-2.3 cm in January and 3.1-3.7 cm in March-April; subsurface flow (interflow + groundwater flow) maximum during April $(4.8-7.5 \mathrm{~cm})$ and May $(2.5-6.6 \mathrm{~cm})$ and minimum during summer months between July-September. Looking at the monthly maximum contribution of water budget components, evapotranspiration contributed more than $90 \%$ of the water budget during months from July-September; surface runoff 31\%, 33.4\%, and 47.7\% in February, November, and March; subsurface flow contributed 70.9\%, 72.7\%, and 79.7\% in January, April, and December.

The monthly water budget components simulated by HSPF and CANWET were compared for evapotranspiration, surface runoff, subsurface runoff, and stream flow. The comparison of evapotranspiration indicated that both the model simulations followed similar trend with peak ET simulated in June and minimal in December, January, and February (Fig. 3). CANWET over predicts ET than HSPF by $10-12 \%$ during summer months between June-September. Since ET values cannot be measured directly, it is hard to say which model's prediction is better. While the annual ET simulations are within permissible range, the simulations will be analyzed further after comparing other components of water budget.

The monthly comparison of surface runoff simulated by HSPF and CANWET showed that proportionate monthly surface runoff was produced within the seasons by both the models, however; there was discrepancy in the volumes produced. The difference is resulting since CANWET, in the current version, uses one curve number value for entire simulation period for one type of land use, whereas, it is possible to change values of infiltration rate and other related parameters temporally for HSPF simulation. In the current study, infiltration rate was reduced in HSPF for winter and early spring period to accommodate frozen conditions.

The monthly subsurface flow analysis indicates that there is mixed variation in subsurface flow simulated monthly within the seasons (Fig. 3). CANWET simulated higher subsurface flow during May and 
less subsurface flow during summer months. The reason for low subsurface flow in CANWET is that CANWET uses single tank approach and evapotranspiration uses moisture that is available in the tank which results in limited moisture remaining to contribute for subsurface flow. Whereas, HSPF uses twotank approach and the amount of groundwater being used for evapotranspiration can be calibrated. The future version of CANWET will have the ability to partition what portion of groundwater contributing towards evapotranspiration (Palmer, 2006).

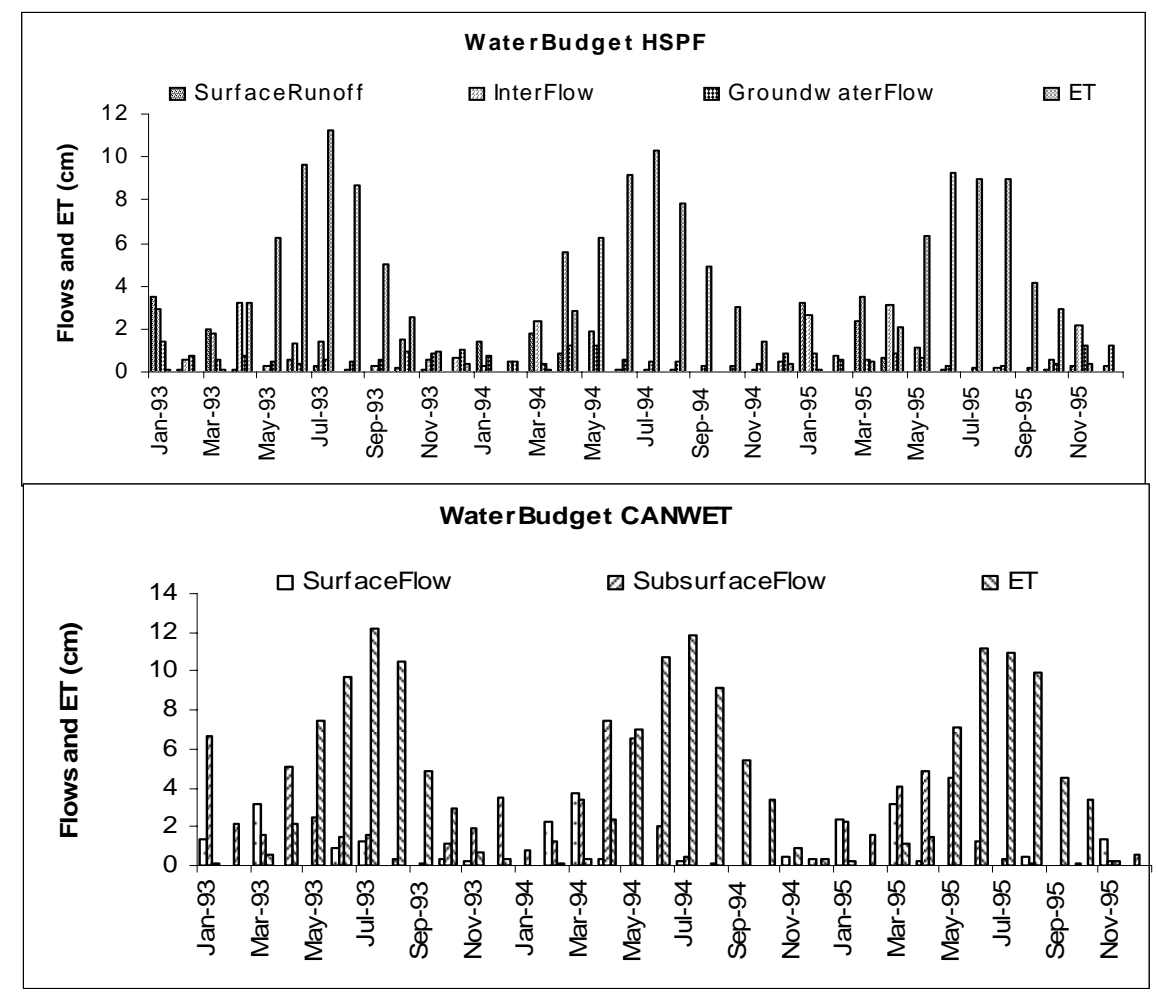

Fig. 3. Monthly water budget simulated by HSPF and CANWET (1993 - 1995)

The total monthly stream flow simulated by HSPF and CANWET was compared with the observed stream flow for the period between 1993 and 1995 (Fig. 4). The comparison revealed a Nash-E of 0.81 and 0.67 for HSPF and CANWET and observed stream flow, respectively. This indicates a good agreement between observed and simulated stream flow by both the models. However, HSPF simulation performs better because of more temporal control on the variables that mimic seasonal variations in the processes.

Daily Stream Flow Analysis

The stream flow analysis was extended for daily comparison between observed stream flow and stream flow simulated by HSPF and CANWET during three years simulation between 1993 and 1995 (Fig. 5). The Nash-E of 0.48 and 0.24 were found between daily observed stream flow and stream flows simulated by HSPF and CANWET, respectively. The scatter chart between daily observed stream flow and daily HSPF and CANWET simulated stream flows presented in Fig. 5 (inset) show strong relation between daily simulated and observed data. HSPF performs better during the summer months due to reasonable simulation of subsurface flow contribution; however, CANWET simulates negligible daily subsurface flows during summer. On the other hand, peaks were reasonably captured by both the models. It is expected that the up coming version of CANWET will give its user opportunity to vary hydrologic parameters temporally suiting the site specific seasonal parameter fluctuations. 


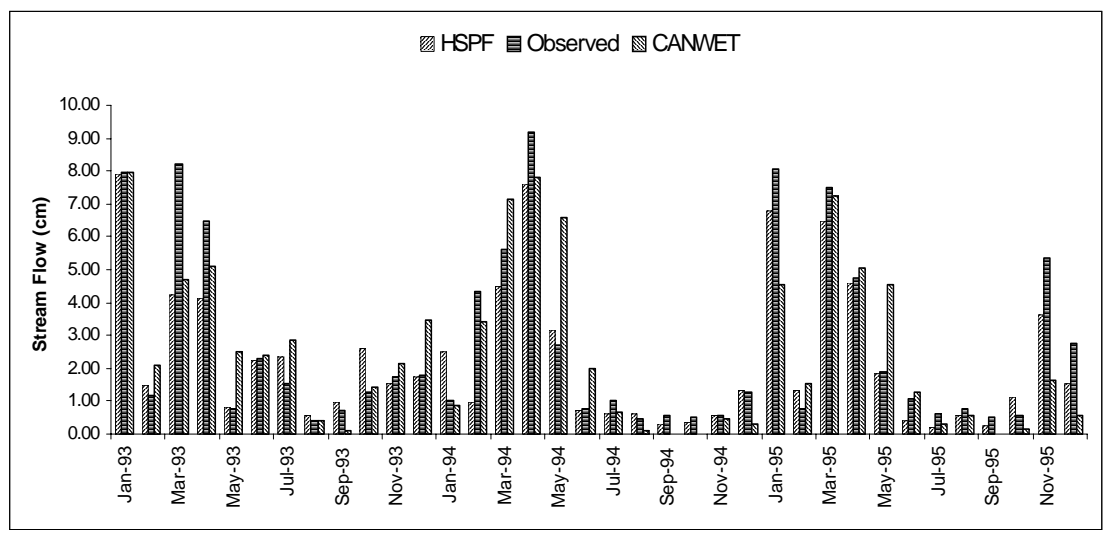

Fig. 4. Comparison of monthly stream flow simulated by HSPF and CANWET (1993 - 1995)
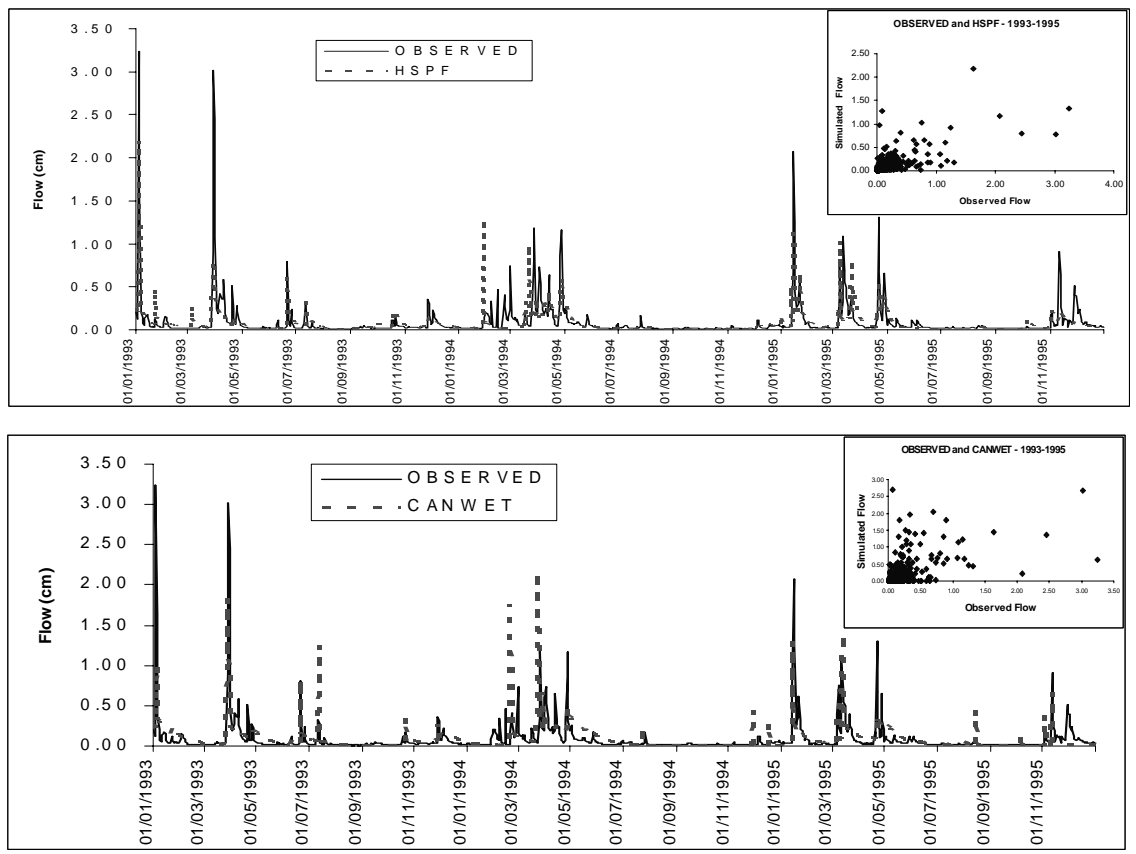

Fig. 5. Comparison of daily observed stream flow and stream flow simulated by HSPF and CANWET (1993 - 1995)

\section{Sediment simulation}

The annual sediment erosion by HSPF was compared with the sediment erosion simulated by USLE and multiplying it with sediment delivery ratio (SDR) of 0.36 based upon the model given by Renfro (1975). HSPF simulates upland sediment erosion as delivered to the stream. Since CANWET uses USLE for simulation of upland soil erosion, the erosion output produced by CANWET was multiplied by the SDR of the watershed (0.36) to achieve upland sediment delivered to the stream as suggest by (USEPA, 2006). Fig. 6 (inset) shows the comparison of annual upland erosion simulated by HSPF and CANWET from 19931995. The outputs for upland sediment delivered to stream are in close agreement with HSPF producing slightly higher sediment than CANWET. 
Further, the monthly sediment yields simulated at the outlet by HSPF and CANWET were compared. There was considerable difference in the monthly simulated sediment yield by both the models. The difference is consistent with the surface runoff variation predictions by both the models (Fig. 3). On the other hand, HSPF also has a module for in-stream sediment deposition and scouring which makes the simulation dynamic for in-stream sediment routing. But in the absence of continuous observed data it is not possible to predict which model is simulating better monthly sediment yield. Both the models predicted sediments with early winter storms (January) and spring storms (March-May) which is general behavior of watersheds in southern Ontario since there is larger contributing area during these periods. The simulated sediment yield is minimal during rest of the year because of lower flows in these periods.

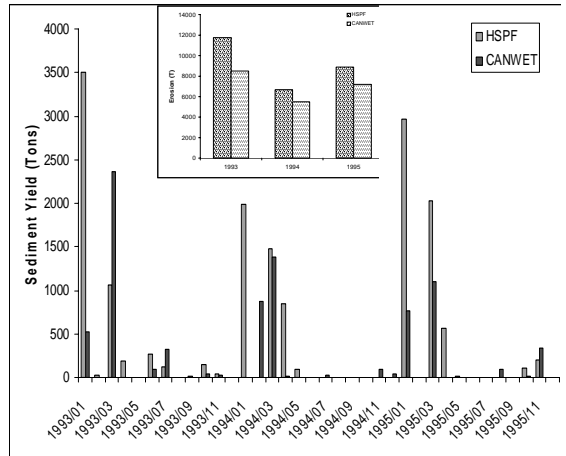

Fig. 6. Comparison of monthly sediment yield and annual erosion (inset) simulated by HSPF and CANWET from 1993 - 1995

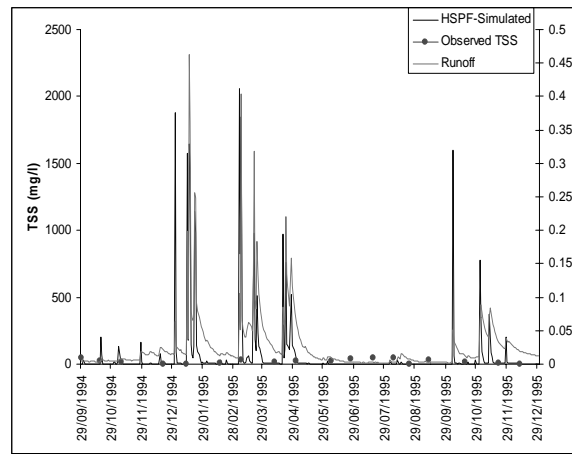

Fig. 7 Comparison of HSPF simulated and observed TSS

The HSPF model also simulates total suspended sediments (TSS) on daily basis which was compared with the available 18 observations from September 1994 to December 1995. Figure 7 reveals that observed data points fall on the non-peak flow days and, therefore, give the base suspended sediment values in the stream. The simulated TSS also showed base values during the times when observed TSS data was available. Figure 7 also reveals that the peaks in TSS were simulated when there were peaks in stream flow. Therefore, the trend in TSS is justified whereas the quantitative verification needs further investigation with the observed data. Since CANWET does not produce daily sediment loads in its current version, it cannot be used for TMDL evaluation whereas HSPF has the capability of evaluating TMDL on watershed scale.

\section{CONCLUSION}

The study concludes that:

- $\quad$ Both HSPF and CANWET partitioned annual water into evapotranspiration, surface runoff, and subsurface flow which is representative of the watersheds with medium soils in southern Ontario. Therefore, either of the model may be used for annual water budgeting.

- Both the models partitioned seasonal water budget components in close agreement and seasonal stream flow simulation by both the models produced high Nash-E (0.83 and 0.81 for HSPF vs observed stream flow and CANWET vs observed stream flow, respectively). Seasonal comparison also reveals that either of the two models can be used for seasonal water budgeting.

- Both the models partitioned monthly water budget components realistically representing hydrology of watersheds in southern Ontario. The monthly simulated stream flow comparison with observed stream flow rendered good correlation (Nash-E $=0.81$ and 0.67 for HSPF vs observed stream flow and CANWET vs observed stream flow, respectively). Apparently HSPF does better predictions than CANWET for monthly water budgeting as it has more temporal control on hydrologic parameters. It is learned that the new version of CANWET will also enable temporal variation in key hydrologic parameters and, therefore, better monthly simulations could be expected.

- The daily comparison of HSPF simulated stream flow with observed stream flow showed a Nash-E of 0.48 while CANWET simulated stream flow showed an $\mathrm{R}^{2}$ of 0.24 with observed stream flow. Since correlation of HSPF with observed stream flow is more promising, HSPF may be preferred over 
CANWET for daily simulations depending upon the accuracy required.

- The upland erosion simulation is comparable for both the models with HSPF also relying on USLE for calibration. Since HSPF has a strong in-stream component for sediment routing, therefore, sediment yield prediction may be more reliable. The conclusion could not be drawn on which model predicts better sediment yield because not much observed data were available to verify the model outputs.

- HSPF needs a higher level of expertise for its application compared to application of CANWET. The number of variables controlling hydrology and sediment in HSPF are much higher compared to CANWET.

\section{REFERENCES}

Al-Abed, N. A. and H. R. Whiteley. 2002. Calibration of the Hydrological Simulation Program Fortran (HSPF) model using automatic calibration and geographical information systems. Hydrological Processes 16(16); 3169-3188.

Anonymous. 2004. CANWET User's Guide. Greenland International Consulting, Collinwood, Canada.

Benham, B. L., K. M. Brannan, G. Yogow, R. W. Zeckoski, T. A. Dillaha, S. Mostaghimi, J.W. Wynn. 2005. Development of bacteria and benthic total maximum daily loads: a case study, Linville Creek, Virginia. JEQ 34(5): 1860-1872.

Bicknell, B.R., J.C. Imhoff, J.L. Kittle, Jr., T.H. Jobes, and A.S. Donigian, Jr., 2001. Hydrological Simulation Program - FORTRAN (HSPF), User's Manual for Version 12.0. USEPA, Athens, Georgia.

Borah, D.K. and M. Bera. 2003. Watershed-Scale Hydrologic and Nonpoint-Source Pollution Models: Review of Mathematical Bases. Trans. ASAE 46(6):1553-1566.

Dickinson, W.T. and R.P. Rudra. 2006. Key Components of Ontario Hydrography. Presentation at A.D.Latornell Conservation Symposium, Alliston, Ontario, Canada. November 15-17, 2006.

Haith, D.A. 2006. Personal communication. Cornell University, Ithaca, NY, USA.

Haith, D.A., R. Mandel, and R. S. Wu. 1992. GWLF. Generalized Watershed Loading Functions, Version 2.0. User’s manual. Dep. Of Agric. And Biol. Eng., Cornell Univ., Ithaca, N.Y.

MOE (Ontario Ministry of Environment). 2006a, News release by the Ontario Ministry of the Environment, (website http://www.ene.gov.on.ca/envision/water/cwa.htm)

MOE (Ontario Ministry of Environment). 2006b. Assessment Report: Draft Guidance Modules, (website http://www.ene.gov.on.ca/envision/water/cwa-guidance.htm)

Negev, M. 1967. A Sediment Model on a Digital Computer, Department of Civil Engineering, Stanford University, Stanford, CA, Technical Report No. 76, 109p.

Nash, J. E. and J. V. Sutcliffe (1970), River flow forecasting through conceptual models part I — A discussion of principles, Journal of Hydrology, 10 (3), 282-290.

Palmer, R. M. 2006. Personal communication. Greenland Consulting Ltd., Collingwood, Canada.

Philip, J.R., 1957. The Theory of Infiltration: 1. The Infiltration Equation and Its Solution. Soil Science 83:345-357.

Renfro, G. W. 1975. Use of erosion equations and sediment delivery ratios for predicting sediment yield. In Present and Prospective technology for Predicting Sediment Yields and Sources, Agricultural Resources Services, ARS-S-40, 33-45. US Dept. Agric., Washington, D.C.

ShuKuang, N., N. B. Chang, J. KaiYu, T. YiHsing. 2006. Soil erosion and non-point source pollution impacts assessment with the aid of multi-temporal remote sensing images. Journal of Environmental Management 79(1): 88-101.

Singh, J., H. V. Knapp, J. G. Arnold, and M. Demissie. 2005. Hydrological modeling of the Iqoquois river watershed using HSPF and SWAT. JAWRA 41(2): 343-360.

USDA-SCS (U.S. Department of Agriculture-Soil Conservation Service), 1972. Hydrology, Section 4, Chapter 4-10. In: national Engineering Handbook. USDA Soil Conservation Service, Washington, D.C.

USEPA (U.S. Environmental Protection Agency), 2000. BASINS Technical Note 6: Estimating Hydrology and Hydraulic Parameters for HSPF. USEPA, Office of Water, EPA-823-R-99-013, Washington D.C.

USEPA (U.S. Environmental Protection Agency), 2001. Better Assessment Science Integrating Point and Nonpoint Sources - BASINS Version 3.0, User's Manual. EPA-823-B-01-001, Washington, D.C.

USEPA (U.S. Environmental Protection Agency), 2006. EPA BASINS Technical Note 8. Sediment Parameter and Calibration Guidance for HSPF. USEPA, Office of Water, 4305, Washington D.C.

Wischmeier, W.H., and D.D. Smith. 1965. Predicting Rainfall Erosion Losses from Cropland East of the Rocky Mountains. U.S. Department of Agriculture, Agricultural Handbook No. 282. 47p. 